\title{
Role of Intercropping and Nitrogen Fertilizer on Management of Peanut and Sesame Root-Rot and Wilt Diseases
}

A.A. Abd El-Baky* and M.A. Abd El-Galil**

* Plant Pathol. Res. Inst., ARC, Giza, Egypt.

** Field Crops Res. Inst., ARC, Giza, Egypt.

\begin{abstract}
Deanut - sesame intercropping was studied under (2:2) and (3:1) pattern with 45,60 and $75 \mathrm{~kg}$ nitrogen/feddan to determine their effect on the total count of bacteria and fungi as well as the incidence of root-rot and wilt diseases (dead plants) and yield components of both crops in Ismailia Agricultural Research Station during 2010 and 2011 growing seasons. Results indicated that intercropping pattern $(2: 2)$ increased the total count of bacteria and fungi isolated from the soil than that in (3:1) pattern. Also, it increased the total count of fungi responsible for root-rot and/or wilt diseases (dead plants) of both crops. Increasing nitrogen fertilizer rate from 45 to $75 \mathrm{~kg}$ nitrogen/feddan increased the total count of fungi and decreased the total count of bacteria. On the other hand, the increase of nitrogen fertilizer rate resulted in increasing the percentages of dead plants of both crops under both intercropping system during the two growing seasons. The values of land equivalent rate (LER) of (2:2) pattern exceeded than $(3: 1)$ pattern. The highest LER was obtained with $(2: 2)$ pattern when fertilized with the highest nitrogen fertilizer rate $(75 \mathrm{~kg} \mathrm{~N} / \mathrm{fed}$.). Results also indicated that the yield of sesame in (2:2) pattern was the superior and the opposite was recorded for peanut in case of $(3: 1)$ pattern. In addition, increasing the dose of nitrogen fertilizer resulted in increasing the values of crop parameters than the other two rates whatever the pattern of the intercropping.
\end{abstract}

Keywords: Fertilizer, intercropping, nitrogen, peanut, root-rot, sesame and wilt.

Peanut (Arachis hypogaea L.) and sesame (Sesamum indicum L.) are vulnerable to attack by several devastative pathogenic air and soilborne fungi causing considerable losses in the yield. Soilborne pathogenic fungi such as Fusarium spp., Macrophomina phaseolina, Aspergillus spp. and Rhizoctonia solani cause root- and pod-rot during the growing season with drastic quantitative and qualitative losses in the yield all over the world (Hilal et al., 1990; Jacobi and Backman, 1994; Mehan et al., 1995; El-Deeb and Ibrahim, 1998; Hasan et al., 2002). Moreover, El-Shehaby and Morsy (2005) reported that losses in the stand may reach 35\% in some fields. Meanwhile, $F$. oxysporum f.sp. sesame, M. phaseolina and $R$. solani are soilborne 
pathogens causing yield losses in sesame ranging from 50 to $100 \%$ of several years (Khalifa, 2003; El-Bramawy, 2003; 2006a; and 2006b). The causal of charcoal rot (M. phaseolina) can infect sesame plants at all stages, where damage can result in poor seedling establishment, pre- and post-emergence damping-off and reduction the activity and productivity of older sesame plants. Major symptoms on infected plants are stunting, chlorosis, premature defoliation, early maturity and death (Aly et al., 2006).

Intercropping system is believed to be more beneficial for small farmers in the low-input, high risky environment of developing world areas. Intercropping can achieve much larger yield than single crops by using environmental resources more fully over time or more efficiently in space (Willey et al., 1983). Intercropping sesame with peanut is an old practice with main objective to reduce labour peak, minimize crop failure risk, provides higher returns and more important help reduce oil gap. The merits of intercropping sesame with peanut have been well documented by many investigators (Abd El-Galil and Moursi, 2004; Toaima et al., 2004 and Abd El-Zaher et al., 2007). Moreover, Gabr et al. (1993) found also that peanut intercropped with sesame at (1:1) row ratio or with various combinations and grown alone gave the highest yield when grown alone. Peanut pod yield was the highest when grown at a ratio of $(1: 1)$ and sown at $100 \%$ of the recommended plant density. Land equivalent ratio (LER) was the highest when peanut and sesame were intercropped at (1:1) row ratio. With respect to groundnut attributes and yield/fed., intercropping treatment at $(2: 2)$ recorded the highest values followed by (1:1) (El-Mihi et al., 1990). Also, Barabasz et al. (2002) mentioned that high dose of $\mathrm{N}$ fertilization increased Arthrobacter and Sterptomyces species by $50 \%$ on the average, and resulted in complete inhibition to Rhizobium and Bradythzobium. They added that $\mathrm{N}$ fertilization enhanced the numbers of bacteria belonging to genera Eubacterium, Pseudomonas, Bacillus and fungi belonging to genera Aspergillus, Fusarium, Penicillium, Verticillium and others. Meanwhile, Abd El-Baky (2005) reported that urea and potassium sulphate at the rate of $50 \mathrm{~kg} / \mathrm{fed}$. significantly reduced basal rot and black mould diseases in onion than $100 \mathrm{~kg} / \mathrm{fed}$. Moreover, Hussein et al. (2002) reported that nitrogen application frequency had significant effect on plant height, number of branches/plant, number of pods/plant, weight of pods/plant, 100-seed weight, shelling percent and pod yield /fed. of peanut. The highest values of yield components and pod yield/fed. were obtained when nitrogen application was frequency used every three days. Increasing or decreasing nitrogen application frequency to one or seven days gave the lowest pod yield/fed. Chuan-Chao et al. (2009) found that intercropping treatments recorded greater total microbial quantity, diversity and a higher ratio of bacteria to fungi than the monocropping. Also, Gangwar et al. (2009) reported that intercropping chickpea with each of linseed, mustard and wheat reduced number of spores of $F$. oxysporum f.sp. ciceri compared to the solid chickpea. However, intercropping significantly reduced the wilt incidence with significant increase in crop yield during two seasons.

This work was designed to study the effect of different types of intercropping peanut with sesame as well as the influence of nitrogen fertilizer rates on the count of bacteria and fungi, incidence of dead plants and other crop parameters.

Egypt. J. Phytopathol., Vol. 42, No. 1 (2014) 


\section{Materials and Methods}

Field experiments were carried out in sandy soil at Ismailia Agric. Res. Station, during the summer of 2010 and 2011 growing seasons. The effects of two intercropping patterns of sesame with peanut, using three rates of nitrogen fertilization (45, 60 and $75 \mathrm{~kg} \mathrm{~N} / \mathrm{fed}$.), on the infection by root-rot and/or wilt diseases as well as yield components, were investigated. The field has a history of high infestation with the causal fungal pathogens of root rot and wilt diseases, i.e. M. phaseolina, $F$. oxysporum, $F$. solani and $R$. solani. Each experiment included 8 treatments of all possible combinations of two intercropping patterns and the abovementioned three rates of nitrogen fertilizer. Sesame (cv. Shandweel 3) and peanut (cv. Giza 6) were planted as follows:

1- Intercropping pattern (3 peanut: 1 sesame) where sesame was planted on one row and peanut was planted on three rows ( $75 \%$ peanut: $25 \%$ sesame).

2- Intercropping pattern ( 2 peanut: 2 sesame) where sesame was planted on two rows and peanut was planted on another two rows (50\% peanut: $50 \%$ sesame).

Wheat was, however, the preceding crop in both seasons. Two seeds of peanut were sown in each hill at $10 \mathrm{~cm}$ apart and 5-7 seeds of sesame were sown in each hill at $15 \mathrm{~cm}$ apart. Thinning was carried out 3 weeks after sowing, into one plant/hill in case of peanut and two plants/hill in case of sesame. Peanut and sesame were sown on $17^{\text {th }}$ and $25^{\text {th }}$ May in 2010 season and $12^{\text {th }}$ and $22^{\text {nd }}$ May in 2011 growing season, respectively. Each plot was $14.4 \mathrm{~m}^{2}$ ( $4.8 \mathrm{~m}$ in length $\mathrm{x} 3$ meters in width). Each plot consisted of 8 rows. Split plot design with three replicates was used. Calcium super phosphate $15.5 \%\left(\mathrm{P}_{2} \mathrm{O}_{5}\right)$ at the rate of $200 \mathrm{~kg} / \mathrm{fed}$. was added during land preparation for sowing. Whereas, nitrogen fertilizer was added to peanut and sesame in the form of ammonium nitrate $(33.5 \%)$ at the rate of 45,60 and $75 \mathrm{~kg} \mathrm{~N} /$ fed., just after thinning, just before flowering and at flowering stage. The stand of peanut and that of sesame were calculated at 40 and 60 days after sowing. Peanut and sesame were harvested on $30^{\text {th }}$ and $25^{\text {th }}$ September and $22^{\text {nd }}$ and $28^{\text {th }}$ September in the first and the second season, respectively.

Determination of total counts of bacteria and fungi in the soil:

Plate count technique was followed to determine the total counts of bacteria and fungi in the field soil following harvesting peanut and sesame plants according to the method of Johansen et al. (1960).

In most cases, isolation traits were carried out to through light on the causative fungi. The infected plants were gently up rooted and the roots were examined for symptoms and signs of infection. The roots were washed thoroughly in tap water and cut into small pieces. Root fragments, especially those showing visible lesions were surface sterilized for $3 \mathrm{~min}$. in $1 \%$ of $\mathrm{NaOCl}$, rinsed in sterilized water, placed on PDA medium and incubated on $25{ }^{\circ} \mathrm{C}$ for 10 days. In most cases, colonies formed on the used media were identified according to their morphology features as described by Ellis (1971); Bergey (1985) and Booth (1985). 
Diseases assessment:

Growing peanut and sesame plants were carefully examined during each tested season and the percentages of dead plants resulted from root rot and/or wilt diseases were recorded and the efficiency of treatment was assessed as follows:

Treatment efficiency $(\%)=\mathrm{A}-\mathrm{B} / \mathrm{A} \times 100$

Whereas: A: Number of dead plants due to disease infection of the control. B: Number of dead plants due to disease infection of the treatment.

Also, the reduction of cfu was counted using the following equation:

$\mathrm{CFU}$ reduction $(\%)=\mathrm{A}-\mathrm{B} / \mathrm{A} \times 100$

Whereas: A: Number of colony form unit in control.

B: Number of colony form unit in treatment.

Competitive relationships:

Land equivalent ratio (LER) was assessed using the following equation as described by Willey (1979):

$$
\mathrm{LER}=\mathrm{Y}_{\mathrm{ab}} / \mathrm{Y}_{\mathrm{aa}}+\mathrm{Y}_{\mathrm{ba}} / \mathrm{Y}_{\mathrm{bb}}
$$

Whereas: $Y_{a a}$ is pure stand yield of species a; $Y_{b b}$ is pure stand yield of species $b$; $Y_{a b}$ is mixture yield of $a$ (when combined with $b$ ) and $Y_{b a}$ is mixture yield of $b$ (when combined with a)

Statistical analysis:

Data were analysed by M-STAT software for comparison of the mean values and the two seasons by L.S.D. at 5\% level. Response equations were calculated according to Snedecor and Cochran (1998).

\section{Res u l t s}

Effect of intercropping and nitrogen fertilization:

1- Effect on the total counts of fungi causing root-rot and wilt diseases:

Results in Table (1) indicate that intercropping peanut and sesame in two systems, i.e. 3 peanut : 1 sesame and 2 peanut : 2 sesame, resulted in variable effects on the total counts of fungi causing root-rot and wilt diseases. The first pattern was more effective than the second one in this regard during 2010 and 2011 growing seasons. During 2010, results were significantly with $F$. oxysporum, M. phaseolina and $R$. solani. The two intercropping patterns reduced the colony forming units (cfu) of $M$. phaseolina and $R$. solani compared to monocropping of peanut and sesame, but this trend was not noticed in case of the two species of the genus Fusarium.

Intercropping system (3:1) was more effective than (2:2) system on reduction of cfu of soilborne fungi related to root-rot and wilt diseases. This effect was significant with $F$. oxysporum, $M$. phaseolina and $F$. solani, while it was not significant with $R$. solani. Meanwhile, the two intercropping patterns decreased the cfu of $M$. phaseolina and $R$. solani. Moreover, increasing in the cfu of the two species of genus Fusarium was observed, compared to monocropping peanut and sesame plants. 
Table 1. Effect of two intercropping systems in an interaction with nitrogen fertilization rates on the total count of some soilborne fungi under field conditions during 2010 and 2011 growing season

\begin{tabular}{|c|c|c|c|c|c|c|c|c|}
\hline \multirow{3}{*}{$\begin{array}{c}\text { Treatment, } * \\
\text { character \& } \\
\text { intercropping pattern }\end{array}$} & \multicolumn{4}{|c|}{2010} & \multicolumn{4}{|c|}{2011} \\
\hline & \multicolumn{4}{|c|}{ Count of CFU $\left(\mathrm{X} \mathrm{10} 0^{3}\right)$} & \multicolumn{4}{|c|}{ Count of $\mathrm{CFU}\left(\mathrm{X} \mathrm{10} 0^{3}\right)$} \\
\hline & FO & FS & $\mathrm{MPH}$ & RS & FO & FS & MPH & RS \\
\hline $\mathrm{A}_{1}$ & 16.7 & 20.2 & 22.8 & 26.1 & 41.3 & 120.5 & 239.0 & 14.8 \\
\hline $\mathrm{A}_{2}$ & 26.0 & 38.5 & 42.6 & 35.9 & 71.4 & 346.9 & 396.5 & 21.4 \\
\hline LSD at $5 \%$ & 5.1 & 18.0 & 12.8 & 5.1 & 7.2 & 81.8 & 9.1 & n.s \\
\hline Peanut solid & 25.4 & 31.9 & 72.2 & 66.7 & 37.4 & 33.9 & 460.0 & 36.7 \\
\hline Sesame solid & 14.2 & 30.9 & 65.2 & 56.7 & 27.2 & 81.6 & 551.0 & 24.3 \\
\hline \multicolumn{9}{|l|}{ Interaction: } \\
\hline$\overline{\mathrm{A}_{1} \mathrm{~F}_{1}}$ & 10.4 & 10.4 & 7.4 & 13.9 & 6.8 & 61.2 & 0.0 & 6.9 \\
\hline $\mathrm{A}_{2} \mathrm{~F}_{1}$ & 10.9 & 24.1 & 7.0 & 29.6 & 13.6 & 234.7 & 0.0 & 10.2 \\
\hline Mean & 10.7 & 17.3 & 7.2 & 21.8 & 10.2 & 148.0 & 0.0 & 8.6 \\
\hline $\mathrm{A}_{1} \mathrm{~F}_{2}$ & 13.9 & 10.4 & 13.8 & 20.8 & 20.4 & 101.9 & 346.9 & 13.9 \\
\hline $\mathrm{A}_{2} \mathrm{~F}_{2}$ & 25.9 & 40.7 & 55.6 & 30.9 & 20.4 & 346.9 & 583.3 & 23.8 \\
\hline Mean & 19.9 & 25.6 & 34.7 & 25.9 & 20.4 & 224.4 & 465.1 & 18.9 \\
\hline $\mathrm{A}_{1} \mathrm{~F}_{3}$ & 25.4 & 39.9 & 47.1 & 43.5 & 96.6 & 198.4 & 370.0 & 23.6 \\
\hline $\mathrm{A}_{2} \mathrm{~F}_{3}$ & 41.2 & 50.7 & 65.3 & 47.1 & 180.3 & 459.2 & 606.1 & 30.3 \\
\hline Mean & 33.3 & 45.3 & 56.2 & 45.3 & 138.4 & 328.8 & 488.1 & 26.9 \\
\hline LSD at $5 \%$ & 10.1 & 9.0 & 13.1 & 9.3 & 96.5 & 141.1 & 21.9 & 8.1 \\
\hline
\end{tabular}

* $\mathrm{A}_{1}=$ Intercropping 3:1, $\mathrm{A}_{2}=$ Intercropping 2:2, $\mathrm{F}_{1}=45 \mathrm{~kg} / \mathrm{fed} ., \mathrm{F}_{2}=60 \mathrm{~kg} / \mathrm{fed} ., \mathrm{F}_{3}=75 \mathrm{~kg} / \mathrm{fed}$. $\mathrm{FO}=F$. oxysporum, $\mathrm{FS}=F$. solani, $\mathrm{MPH}=M$. phaseolina and $\mathrm{RS}=R$. solani .

Results also show that the same trend, being in 2010 for the effect of intercropping systems $(3: 1)$ and (2:2), was found in 2011 season with a few differences. The interaction between intercropping pattern and nitrogen fertilization on cfu of the isolated fungi was significant in all traits. Moreover, results of 2010 season showed that within a low dose of $\mathrm{N}$ fertilizer (45 kg N/fed.) no significant difference was detected between $F$. oxysporum, and $M$. phaseolina cfu. Meanwhile, this difference was significant in case of $F$. solani and $R$. solani. On the other side, significant differences were found among all fungi, with exception of $R$. solani.

The combination between intercropping pattern and nitrogen fertilization on $\mathrm{cfu}$ of isolated fungi was significant in all traits. Results of 2011 season showed that within a low dose of $\mathrm{N}$ fertilizer (45 kg N/fed.) no significant difference was detected among all fungi. On the other hand, significant differences were detected within moderate dose of nitrogen (60 kg N/fed.) in all fungi except for $F$. oxysporum, but at a high dose $(75 \mathrm{~kg} / \mathrm{fed}$.) the effect of interaction was significant in case of $M$. phaseolina and $F$. solani and non-significantly with $F$. oxysporum and $R$. solani. Generally, total count of cfu was increased by increasing the dose of nitrogen fertilizer whatever intercropping system applied. 


\section{2- Effect on the total counts of bacteria and fungi isolated from soil:}

The effect of different intercropping systems and nitrogen fertilization and their combination on the total of bacterial and fungal counts in the tested field soil are tabulated in Table (2). Concerning the intercropping effects, results show that (3:1) intercropping system decreased the total count of fungi with significant differences in both seasons. Meanwhile, opposite results were found with $(2: 2)$ intercropping system, being 749.3 and $558.9 \times 10^{3}$ during 2010 and 2011, respectively, compared with solid peanut $\left(565.7 \times 10^{3}\right)$. Whereas, both intercropping systems increased the total count of fungi compared with solid sesame plants. Regarding the bacterial cfu count, (3:1) and (2:2) intercropping patterns increased the total count of the isolated bacteria, being 3.9 and $3.5 \times 10^{6}$ during 2010 and 4.and $4.5 \times 10^{6}$ during 2011, respectively, compared to solid peanut, being 3.1 and $3.2 \times 10^{6}$ and to sesame sole, being, $2.8 \times 10^{6}$ and $2.5 \times 10^{6}$ during the aforementioned seasons, respectively.

Table 2. Effect of two intercropping systems and interaction with fertilization rates of nitrogen on the total count of soil bacteria and fungi during 2010 and 2011 growing seasons

\begin{tabular}{|c|c|c|c|c|c|c|}
\hline \multirow{3}{*}{ Treatment $*$} & \multicolumn{3}{|c|}{$\begin{array}{l}\text { (CFU) of bacteria and fungi } \\
\text { of soil at } 2010\end{array}$} & \multicolumn{3}{|c|}{$\begin{array}{l}\text { (CFU) of bacteria and fungi } \\
\text { of soil at } 2011\end{array}$} \\
\hline & \multirow{2}{*}{ Bacteria $\times 10^{6}$} & \multicolumn{2}{|c|}{ Fungi $\times 10^{3}$} & \multirow{2}{*}{ Bacteria $\times 10^{6}$} & \multicolumn{2}{|c|}{ Fungi $\times 10^{3}$} \\
\hline & & Act. & Trans. & & Act. & Trans. \\
\hline $\mathrm{A}_{1}$ & 3.9 & 400.0 & 2.4 & 3.5 & 310.5 & 2.4 \\
\hline $\mathrm{A}_{2}$ & 4.9 & 749.3 & 2.8 & 4.5 & 558.9 & 2.7 \\
\hline LSD at $5 \%$ & n.s & -- & 0.1 & n.s & -- & 0.1 \\
\hline Peanut sole & 3.1 & 565.7 & & 3.2 & 495.7 & \\
\hline Sesame sole & 2.8 & 158.5 & & 2.5 & 157.2 & \\
\hline \multicolumn{7}{|l|}{ Interaction: } \\
\hline $\mathrm{A}_{1} \mathrm{~F}_{1}$ & 4.9 & 65.7 & 1.8 & 4.6 & 59.2 & 1.8 \\
\hline $\mathrm{A}_{2} \mathrm{~F}_{1}$ & 4.7 & 185.6 & 2.7 & 5.1 & 180.1 & 2.6 \\
\hline Mean & 4.8 & 125.7 & 2.3 & 4.8 & 119.7 & 2.2 \\
\hline $\mathrm{A}_{1} \mathrm{~F}_{2}$ & 2.1 & 483.0 & 1.8 & 4.3 & 352.0 & 1.7 \\
\hline $\mathrm{A}_{2} \mathrm{~F}_{2}$ & 5.6 & 651.4 & 2.3 & 5.0 & 520.4 & 2.3 \\
\hline Mean & 3.9 & 567.2 & 2.6 & 4.7 & 436.2 & 2.5 \\
\hline $\mathrm{A}_{1} \mathrm{~F}_{3}$ & 3.8 & 927.6 & 3.0 & 1.4 & 632.6 & 2.8 \\
\hline $\mathrm{A}_{2} \mathrm{~F}_{3}$ & 5.4 & 1135.1 & 3.1 & 3.6 & 863.8 & 2.9 \\
\hline Mean & 4.6 & 1031.4 & 3.1 & 2.5 & 748.2 & 2.9 \\
\hline LSD at $5 \%$ & n.s & -- & 0.1 & n.s & -- & 0.1 \\
\hline
\end{tabular}

* $\mathrm{A}_{1}, \mathrm{~A}_{2}, \mathrm{~F}_{1}, \mathrm{~F}_{2}$ and $\mathrm{F}_{3}$ : As described in footnote of Table (1).

The interaction between intercropping pattern and nitrogen fertilization showed no significant differences in the total count of bacteria. However, cfu count of bacteria was increased at (2:2) intercropping pattern more than (3:1) intercropping pattern at the same dose of nitrogen fertilizer. On the other hand, significant differences were found at different treatments. Generally, cfu of fungi was increased with increasing the nitrogen rate. Opposite results were found with bacterial cfu whatever intercropping pattern. 


\section{3- Effect on the percentages of dead plants:}

Concerning the effect of two intercropping patterns and the three nitrogen doses on the percentages of dead plants due to the infection by root- rot and/ or wilt diseases during 2010 and 2011, results in Table (3) show that intercropping peanut and sesame in (3:1) and (2:2) systems resulted in significant reduction in the percentage of dead plants compared to control treatment. However, sesame was more responded to intercropping system than peanut, where the percentages of dead plants were greatly reduced than the sole crop. In addition, (3:1) system was, to somewhat, more efficient in this regard, being 21.95 and $16.17 \%$ than $(2: 2)$ system, being 25.06 and $17.88 \%$ for peanut and sesame, respectively. Control treatment recorded 27.47 and $22.17 \%$ for both crops, respectively.

Table 3. Effect of two intercropping systems on the percentages of dead plants of peanut and sesame

\begin{tabular}{|c|c|c|c|c|c|c|}
\hline \multirow[t]{2}{*}{ Intercropping pattern $*$} & \multicolumn{2}{|c|}{$\begin{array}{l}\text { Peanut dead plants } \\
(\%)\end{array}$} & \multirow[t]{2}{*}{ Mean } & \multicolumn{2}{|c|}{$\begin{array}{c}\text { Sesame dead plants } \\
(\%)\end{array}$} & \multirow[t]{2}{*}{ Mean } \\
\hline & 2010 & 2011 & & 2010 & 2011 & \\
\hline A1 $(3: 1)$ & 21.11 & 22.78 & 21.95 & 15.67 & 16.67 & 16.17 \\
\hline A2 (2:2) & 23.67 & 26.44 & 25.06 & 16.65 & 19.11 & 17.88 \\
\hline $\begin{array}{c}\text { Control } \\
\text { (sole monocropping) }\end{array}$ & 25.60 & 29.33 & 27.47 & 20.67 & 23.67 & 22.17 \\
\hline Mean & 23.46 & 26.18 & ------ & 18.33 & 19.82 & --- \\
\hline General mean & \multicolumn{2}{|c|}{24.82} & ------ & \multicolumn{2}{|c|}{19.08} & --- \\
\hline $\begin{array}{l}\text { LSD at } 5 \% \text { for: } \\
\text { Intercropping patterns (I) } \\
\text { Season (S) } \\
\text { Ix S }\end{array}$ & \multicolumn{2}{|r|}{2.1} & & & $\begin{array}{l}2.2 \\
\text { n.s } \\
\text { n.s }\end{array}$ & \\
\hline
\end{tabular}

$* \mathrm{~A}_{1}$ and $\mathrm{A}_{2}$ : As described in footnote of Table (1).

Results in Table (4) reveal that both nitrogen rates, i.e. 45 and $60 \mathrm{~kg} / \mathrm{fed}$. resulted in significant reduction to dead plants of both peanut and sesame compared with $75 \mathrm{~kg} / \mathrm{fed}$. In addition, rate of $60 \mathrm{~kg} / \mathrm{fed}$. more efficient in this regard than $75 \mathrm{~kg} / \mathrm{fed}$. Moreover, sesame dead plants were lower than that of peanut.

Results presented in Table (5) show the effect of interaction between intercropping peanut and sesame with 3:1 and 2:2 intercropping systems and nitrogen rates 45,60 and $75 \mathrm{~kg} / \mathrm{fed}$.

In general, in intercropping (2:2) system, whatever the dose of nitrogen used, high number of dead plants was occurred. Moreover, obtained results indicate that the lowest percentages of dead plants for both peanut and sesame were occurred in case of $A_{1} F_{1}$, being 20.0 and $14.3 \%$, respectively, followed by $A_{1} F_{2}$, in case of peanut, being $21.66 \%$ and $\mathrm{A}_{2} \mathrm{~F}_{2}$ in case of sesame, being $16.5 \%$. Meanwhile, the highest percentages of dead plants were occurred in case of $\mathrm{A}_{2} \mathrm{~F}_{3}$, being 26.8 and $19.5 \%$, respectively, followed by $\mathrm{A}_{2} \mathrm{~F}_{2}$, in case of peanut, being $25.0 \%$ and $\mathrm{A}_{1} \mathrm{~F}_{3}$ in case of sesame, being $18.0 \%$. 
Table 4. Effect of three levels of nitrogen fertilizer on the percentages of dead plants of peanut and sesame

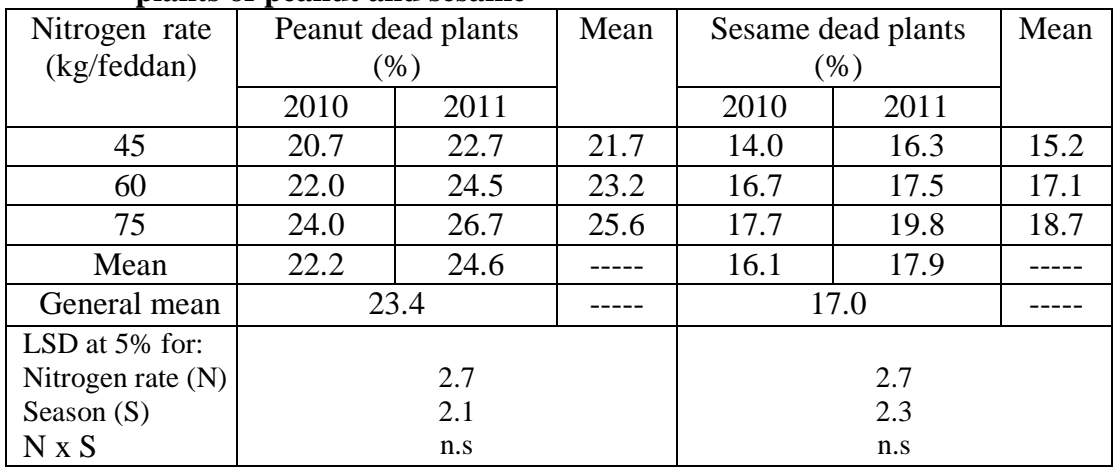

Table 5. Effect of the interaction between intercropping pattern and nitrogen fertilization rates on the percentages of dead plants of peanut and sesame

\begin{tabular}{|c|c|c|c|c|c|c|c|}
\hline \multirow{2}{*}{$\begin{array}{l}\text { Intercropping/ } * \\
\text { Nitrogen rate }\end{array}$} & \multicolumn{2}{|c|}{$\begin{array}{c}\text { Peanut dead plants } \\
(\%)\end{array}$} & \multirow[t]{2}{*}{ Mean } & \multicolumn{2}{|c|}{$\begin{array}{c}\text { Sesame dead plants } \\
(\%)\end{array}$} & \multirow[t]{2}{*}{ Mean } & \multirow{2}{*}{$\begin{array}{c}\text { General } \\
\text { mean }\end{array}$} \\
\hline & 2010 & 2011 & & 2010 & 2011 & & \\
\hline $\mathrm{A}_{1} \mathrm{~F}_{1}$ & 19.3 & 20.7 & 20.0 & 13.7 & 15.0 & 14.3 & 17.2 \\
\hline $\mathrm{A}_{2} \mathrm{~F}_{1}$ & 20.7 & 24.7 & 22.7 & 16.0 & 17.7 & 16.8 & 19.7 \\
\hline $\mathrm{A}_{1} \mathrm{~F} 2$ & 20.0 & 23.3 & 22.0 & 17.3 & 16.3 & 16.8 & 19.4 \\
\hline $\mathrm{A}_{2} \mathrm{~F}_{2}$ & 23.3 & 26.7 & 25.0 & 14.3 & 18.7 & 16.5 & 20.7 \\
\hline $\mathrm{A}_{1} \mathrm{~F}_{3}$ & 23.3 & 25.3 & 24.3 & 17.3 & 18.7 & 18.0 & 21.2 \\
\hline $\mathrm{A}_{2} \mathrm{~F}_{3}$ & 25.7 & 28.0 & 26.8 & 18.0 & 21.0 & 19.5 & 23.2 \\
\hline Mean & 22.1 & 24.8 & 23.4 & 16.1 & 17.9 & 17.0 & ----- \\
\hline General mean & \multicolumn{2}{|c|}{.42} & \begin{tabular}{l|l}
---- \\
\end{tabular} & \multicolumn{2}{|c|}{17.00} & ----- & ----- \\
\hline LSD at $5 \%$ for: & \multirow{2}{*}{\multicolumn{3}{|c|}{2.49}} & \multirow{2}{*}{\multicolumn{3}{|c|}{$n_{S}$}} & \\
\hline Intercropping patterns (I) & & & & & & & \\
\hline Nitrogen rate $(\mathrm{N})$ & \multicolumn{3}{|c|}{3.22} & \multicolumn{3}{|c|}{3.80} & \\
\hline Season $(\mathrm{S})$ & \multicolumn{3}{|c|}{2.49} & \multicolumn{3}{|c|}{2.65} & \\
\hline $\mathrm{N} \times \mathrm{I}$ & \multicolumn{3}{|c|}{ n.s } & \multicolumn{3}{|c|}{ n.s } & \\
\hline S x I & \multicolumn{3}{|c|}{ n.s } & \multicolumn{3}{|c|}{ n.s } & \\
\hline $\mathrm{N} \times \mathrm{S}$ & \multirow{2}{*}{\multicolumn{3}{|c|}{ n.s }} & \multirow{2}{*}{\multicolumn{3}{|c|}{ n.s }} & \\
\hline I $\times N \times S$ & & & n.s & & n.s & & \\
\hline
\end{tabular}

$* \mathrm{~A}_{1}, \mathrm{~A}_{2}, \mathrm{~F}_{1}, \mathrm{~F}_{2}$ and $\mathrm{F}_{3}$ : As described in footnote of Table (1).

4- Effect on the competitive relationships:

Results presented in Table (6) reveal that the relative yield (RYs) of peanut was higher than sesame in both seasons under the studied intercropping patterns. Meanwhile, the reverse was true for RYs of sesame. These observations were true in both seasons and explain the nature of competition between both components in the intercropping pattern. Also, recorded results of land utilization rate indicate that all 
Table 6. Effect of the interaction between intercropping patterns and nitrogen fertilization rates on competitive relationships and yield advantageous during 2010 and 2011growing seasons

\begin{tabular}{|c|c|c|c|c|c|c|}
\hline \multirow[b]{2}{*}{ Character } & \multicolumn{3}{|c|}{2010} & \multicolumn{3}{|c|}{2011} \\
\hline & $\begin{array}{c}\mathrm{RY} * \\
\text { peanut }\end{array}$ & $\begin{array}{c}\mathrm{RY} \\
\text { sesame }\end{array}$ & LER & $\begin{array}{c}\mathrm{RY} \\
\text { peanut }\end{array}$ & $\begin{array}{c}\mathrm{RY} \\
\text { sesame }\end{array}$ & LER \\
\hline A1 & 0.83 & 0.54 & 1.37 & 0.81 & 0.41 & 1.22 \\
\hline A2 & 0.80 & 0.64 & 1.44 & 0.79 & 0.52 & 1.31 \\
\hline$\overline{\mathrm{A}_{1} \mathrm{~F}_{1}}$ & 0.80 & 0.51 & 1.30 & 0.77 & 0.39 & 1.16 \\
\hline $\mathrm{A}_{2} \mathrm{~F}_{1}$ & 0.82 & 0.54 & 1.36 & 0.81 & 0.41 & 1.22 \\
\hline $\mathrm{A}_{1} \mathrm{~F}_{2}$ & 0.81 & 0.56 & 1.37 & 0.79 & 0.44 & 1.23 \\
\hline $\mathrm{A}_{2} \mathrm{~F}_{2}$ & 0.81 & 0.61 & 1.42 & 0.80 & 0.48 & 1.28 \\
\hline $\mathrm{A}_{1} \mathrm{~F}_{3}$ & 0.81 & 0.63 & 1.44 & 0.79 & 0.51 & 1.30 \\
\hline $\mathrm{A}_{2} \mathrm{~F}_{3}$ & 0.83 & 0.67 & 1.50 & 0.81 & 0.57 & 1.38 \\
\hline
\end{tabular}

intercropping patterns gained yield advantage, since the estimated values exceeded the unit. However, LER values of $(2: 2)$ pattern exceeded $(3: 1)$ pattern in both seasons. This indicates that increasing sesame population to reach $50 \%$ of solid population did not exert heavy competition between both components. On the other hand, results of the interaction effect between intercropping pattern with nitrogen fertilization rate indicate that the interaction effect was tenaciously bounded by the main variables (the intercropping pattern and the fertilization rate). The values of RYs peanut and sesame and land utilization rate increased gradually and consistently with increasing nitrogen fertilization rate. These values were also greater when peanut was oriented in $(2: 2)$ pattern. As a consequence highest land utilization rate was obtained when the equal alternative pattern $(2: 2)$ was fertilized with the highest rate of nitrogen fertilizer rate $(75 \mathrm{~kg} \mathrm{~N} / \mathrm{fed}$.), whereas, least LER values were associated when (3:1) pattern was fertilized with lowest rate of nitrogen fertilizer ( $45 \mathrm{~kg} \mathrm{~N} / \mathrm{fed}$.). These observations were valid in both seasons. The relative crowding coefficient followed the same trend of change as LER values. However, it is noteworthy mentioning that $\mathrm{k}$ values of sesame were always higher than those of peanut.

5. Effect on the yield and its components:

5.1. Effect on the yield of peanut and its components:

Results in Table (7) indicate that peanut traits were associated with regular trend when sesame and peanut were orientated in two patterns. Results also reveal that the height of peanut plants was higher in the equal alternative pattern rather than peanut: sesame in $(3: 1)$ pattern. The results were similar in both seasons. Nevertheless, difference between the two intercropping patterns was significant in the second season but insignificant in the first season. Pod yield/fed. of peanut in (3:1) pattern was significantly higher than that in the equal alternative system (2:2). Superiority might owe much to the increase in peanut percentage in the intercrop (3:1). However, peanut pod yield/fed. in the check was higher than that in intercropping. 
Table 7. Effect of two intercropping patterns, nitrogen fertilization rates and their interactions on peanut yield and its components during 2010 and 2011 growing seasons

\begin{tabular}{|c|c|c|c|c|c|c|}
\hline \multirow[b]{3}{*}{ Treatment* } & \multicolumn{6}{|c|}{ Peanut yield and its components during } \\
\hline & \multicolumn{3}{|c|}{2010} & \multicolumn{3}{|c|}{2011} \\
\hline & \begin{tabular}{|c|} 
Plant \\
height \\
$(\mathrm{cm})$
\end{tabular} & $\begin{array}{c}\text { Number } \\
\text { of pods } \\
\text { /plant }\end{array}$ & $\begin{array}{c}\text { Pod yield } \\
\text { (Erdab/fed.) }\end{array}$ & \begin{tabular}{|c} 
Plant \\
height \\
$(\mathrm{cm})$
\end{tabular} & $\begin{array}{c}\text { Number } \\
\text { of pods } \\
\text { / plant }\end{array}$ & $\begin{array}{c}\text { Pod yield } \\
\text { (Erdab/fed.) }\end{array}$ \\
\hline $\mathrm{A}_{1}$ & 45.0 & 26.5 & 14.2 & 43.0 & 31.1 & 13.4 \\
\hline $\mathrm{A}_{2}$ & 47.6 & 24.0 & 13.8 & 46.5 & 23.9 & 13.1 \\
\hline L.S.D. at 0.05 & n.s & $*$ & $*$ & $*$ & $*$ & n.s \\
\hline Solid crop (control) & 51.6 & 33.7 & 17.2 & 54.2 & 37.2 & 16.5 \\
\hline \multicolumn{7}{|l|}{ N. fertilizer: } \\
\hline $\mathrm{F}_{1}$ & 44.4 & 24.5 & 13.4 & 41.3 & 27.4 & 12.5 \\
\hline $\mathrm{F}_{2}$ & 45.8 & 24.2 & 14.0 & 45.0 & 28.8 & 13.2 \\
\hline $\mathrm{F}_{3}$ & 48.6 & 27.0 & 14.6 & 47.7 & 29.2 & 13.9 \\
\hline L.S.D. at 0.05 & 0.99 & n.s & 0.24 & 1.46 & 2.14 & 0.40 \\
\hline \multicolumn{7}{|l|}{ Interaction: } \\
\hline$\overline{\mathrm{A}_{1} \mathrm{~F}_{1}}$ & 42.2 & 20.9 & 13.8 & 39.0 & 33.8 & 12.7 \\
\hline $\mathrm{A}_{2} \mathrm{~F}_{1}$ & 44.6 & 23.6 & 14.0 & 43.1 & 33.8 & 13.9 \\
\hline Mean & 43.4 & 22.2 & 13.9 & 41.0 & 33.8 & 13.1 \\
\hline $\mathrm{A}_{1} \mathrm{~F}_{2}$ & 48.2 & 27.5 & 14.7 & 46.4 & 25.7 & 14.0 \\
\hline $\mathrm{A}_{2} \mathrm{~F}_{2}$ & 46.6 & 28.1 & 13.0 & 43.6 & 21.0 & 12.3 \\
\hline Mean & 47.4 & 27.8 & 13.9 & 45.0 & 23.3 & 13.2 \\
\hline $\mathrm{A}_{1} \mathrm{~F}_{3}$ & 47.1 & 24.9 & 13.8 & 46.9 & 23.9 & 13.0 \\
\hline $\mathrm{A}_{2} \mathrm{~F}_{3}$ & 49.0 & 26.6 & 14.4 & 49.0 & 26.7 & 13.9 \\
\hline Mean & 48.1 & 25.7 & 14.1 & 47.9 & 25.3 & 13.4 \\
\hline L.S.D. at 0.05 & 1.40 & n.s & 0.33 & 2.06 & 3.02 & 0.56 \\
\hline
\end{tabular}

* $\mathrm{A}_{1}, \mathrm{~A}_{2}, \mathrm{~F}_{1}, \mathrm{~F}_{2}$ and $\mathrm{F}_{3}$ : As described in footnote of Table (1).

Also, obtained results (Table 7) indicate that there was consistent and gradual increase in growth, yield and yield components of peanut with increasing the rate of nitrogen fertilization from $45 \mathrm{~kg} \mathrm{~N} / \mathrm{fed}$. to $75 \mathrm{~kg} \mathrm{~N} / \mathrm{fed}$. Differences were significant in both seasons within all traits. Results also indicate that the efficiency of nitrogen fertilization increase with increasing the dose of nitrogen fertilization up to the highest rate in both seasons.

The interaction effect between the intercropping patterns and nitrogen fertilization on growth, yield and yield components of peanut was significant in all traits in both seasons, except in case of the average number of pods. Nevertheless, it is evident that peanut plant heights increased gradually with increasing the nitrogen fertilizer rate up to the highest rate $(75 \mathrm{~kg} \mathrm{~N} / \mathrm{fed}$.) whatever the intercropping pattern. Similar trend was also observed for pod yield/fed. Also, results of the interaction revealed that the maximum pod yield/fed. was obtained when peanut received the moderate rate of nitrogen and arranged in $(3: 1)$ pattern, whereas, minimum yield was obtained when peanut received the same rate of nitrogen fertilizer (60 kg N/fed.) and the plants were arranged in (2:2) pattern. 


\subsection{Effect on the yield of sesame and its components:}

Results presented in Table (8) indicate that intercropping pattern significantly affected sesame plant heights. Also, sesame and peanut orientated in the alternative system (2:2) resulted in higher sesame plant rather than arranging both components in $(3: 1)$ system. In most cases, nitrogen fertilizer rate significantly affected the crop parameters. Results also indicate that the values of all traits were increased with increasing the rate of nitrogen fertilizer. In the first season, sesame yield recorded $162.4,170.8$ and $179.5 \mathrm{~kg} / \mathrm{fed}$., whereas it was $164.3,175.2$ and $191.2 \mathrm{~kg} / \mathrm{fed}$. in the $2^{\text {nd }}$ season under the three levels of nitrogen fertilization $(45,60$ and $75 \mathrm{~kg} \mathrm{~N} / \mathrm{fed}$.). The effect of interaction between the intercropping pattern and rate of $\mathrm{N}$ fertilization was significant in all yield components. Values of yield/fed. were increased with increasing nitrogen fertilizer rate whatever the intercropping pattern was carried out. On the other hand, maximum yield/fed. was associated with the highest rate of nitrogen fertilization (75 kg N/fed.) and sesame and peanut were arranged in (2:2) pattern, whereas, the minimum yield was obtained when the lowest rate of nitrogen (45 kg N/fed.) was used and both crops were arranged in (3:1) pattern.

Table 8. Effect of two intercropping patterns, nitrogen fertilization rates and their interaction on yield and its components of sesame during 2010 and 2011 growing season

\begin{tabular}{|c|c|c|c|c|c|c|}
\hline \multirow[b]{3}{*}{ Treatment* } & \multicolumn{6}{|c|}{ Sesame yield and its components } \\
\hline & \multicolumn{3}{|c|}{2010} & \multicolumn{3}{|c|}{2011} \\
\hline & $\begin{array}{l}\text { Plant } \\
\text { height } \\
(\mathrm{cm})\end{array}$ & $\begin{array}{c}\text { Number of } \\
\text { capsules } \\
\text { /plant }\end{array}$ & $\begin{array}{c}\text { Seed } \\
\text { yield/fed. } \\
(\mathrm{kg})\end{array}$ & $\begin{array}{l}\text { Plant } \\
\text { height } \\
(\mathrm{cm})\end{array}$ & $\begin{array}{l}\text { Number of } \\
\text { capsules } \\
\text { /plant }\end{array}$ & $\begin{array}{c}\text { Seed } \\
\text { yield/fed. } \\
(\mathrm{kg})\end{array}$ \\
\hline $\mathrm{A}_{1}$ & 72.7 & 24.5 & 155.8 & 71.6 & 17.4 & 155.6 \\
\hline $\mathrm{A}_{2}$ & 77.2 & 27.4 & 186.0 & 86.6 & 22.5 & 198.2 \\
\hline L.S.D. at 0.05 & $*$ & n.s & $*$ & $*$ & n.s & $*$ \\
\hline Solid crop (control) & 90.0 & 36.4 & 291.4 & 96.7 & 35.6 & 379.3 \\
\hline \multicolumn{7}{|l|}{ N. fertilizer rates } \\
\hline $\mathrm{F}_{1}$ & 67.9 & 23.1 & 162.4 & 73.4 & 17.9 & 164.3 \\
\hline $\mathrm{F}_{2}$ & 74.4 & 25.9 & 170.8 & 78.9 & 21.7 & 175.2 \\
\hline $\mathrm{F}_{3}$ & 82.5 & 28.9 & 179.5 & 85.1 & 20.3 & 191.2 \\
\hline L.S.D. at 0.05 & 1.3 & 1.2 & 4.4 & 1.3 & n.s & 3.4 \\
\hline \multicolumn{7}{|l|}{ Interaction: } \\
\hline $\mathrm{A}_{1} \mathrm{~F}_{1}$ & 64.7 & 21.6 & 147.3 & 65.1 & 14.1 & 145.3 \\
\hline $\mathrm{A}_{2} \mathrm{~F}_{1}$ & 72.5 & 24.4 & 157.0 & 71.7 & 17.8 & 155.5 \\
\hline Mean & 68.6 & 23.0 & 152.1 & 68.4 & 16.0 & 150.4 \\
\hline $\mathrm{A}_{1} \mathrm{~F}_{2}$ & 80.7 & 27.4 & 163.1 & 78.0 & 20.2 & 165.9 \\
\hline $\mathrm{A}_{2} \mathrm{~F}_{2}$ & 71.0 & 24.6 & 177.5 & 81.6 & 21.7 & 183.2 \\
\hline Mean & 75.9 & 16.0 & 170.3 & 79.8 & 20.9 & 174.6 \\
\hline $\mathrm{A}_{1} \mathrm{~F}_{3}$ & 76.3 & 27.4 & 184.6 & 86.1 & 25.5 & 194.9 \\
\hline $\mathrm{A}_{2} \mathrm{~F}_{3}$ & 84.3 & 30.3 & 196.0 & 92.2 & 20.4 & 216.5 \\
\hline Mean & 80.3 & 28.9 & 190.3 & 89.2 & 22.9 & 205.7 \\
\hline L.S.D. at 0.05 & n.s & 1.68 & 6.26 & 1.83 & n.s & 4.81 \\
\hline
\end{tabular}

$* \mathrm{~A}_{1}, \mathrm{~A}_{2}, \mathrm{~F}_{1}, \mathrm{~F}_{2}$ and $\mathrm{F}_{3}$ : As described in footnote of Table (1). 


\section{D i s c us s i o n}

Cultivation a single crops continually may playing a role of negative impact on crop production, microbial activity of soil, microbial diversity and soil fertility. Therefore, intercropping can control crop diseases besides improving the productivity. Obtained results showed that intercropping decreased the spore counts of soilborne fungi in soil. This reduction may be due to the increase in height of sesame plants in case of $(2: 2)$ pattern than $(3: 1)$ pattern, which intern resulted in dramatic change in microclimate within and under the plants, i.e. temperature and relative humidity. This microclimate is an incubator to the pathogens, which led to increase the density of soil microorganisms in case of (2:2) pattern. Meanwhile, (cfu) of $F$. oxysporum and $F$. solani were increased compared to solid peanut and sesame plants. Both Fusarium species are considered cosmopolitan species and have been reported to occur in a wide range of climatic regions such as tropical, arid, Mediterranean regions and the Arctic (Sangalang et al., 1995). Besides forest soils, F. solani can also be found in native soils such as in subtropical, semi-arid and grassland soils (Burgess and Summerell, 1992) and in desert soils (El-Gindy and Saad, 1990). The effect of $\mathrm{N}$ fertilization rate on the spore count of fungi causing root rot and wilt diseases of peanut and sesame plants showed that all fungi were significantly increased gradually with increasing nitrogen fertilizer rate. These results are in line with those obtained by Barabasz et al. (2002) who found that increasing nitrogen fertilizer rates led to increase the count of some fungi belonging to genera Aspergillus, Fusarium, Penecillium, Verticillium and others. They also stated that mineral fertilization strongly affected the number of microorganisms and qualitative selection of whole communities of soil microorganisms.

Soil microbial communities play an important role of competition against pathogens (Chuan-Chao et al., 2009). Cultivation of continuous monocropping may result unbalance ratio between fungi and bacteria, therefore expedite copiousness of soilborne pathogens in soil and rhizosphere (Ryszkowski et al., 1998). These results are in agreement with those obtained by Gangwar et al. (2009) and Mahmoud et al. (2008) who studied the influence of intercropping soybean and maize on soybean damping-off and relevant effect on the rhizosphere microorganisms. They found that high numbers of microorganisms were found in the (2:2) pattern followed by $(2: 1)$. In addition, Botros (1988) mentioned that root exudates of crops under intercropping conditions may contain some vitamins regulators which increase the number and activity of soil microorganisms. On the other hand, $\mathrm{N}$ fertilization effects caused increasing in the total count of fungi and decreasing in the total count of bacteria. These effects may be associated with the changes in soil $\mathrm{pH}$. These results are in agreement with those reported by Barabasz et al. (2002) who stated that higher nitrosamine concentrations were observed in acid soils with low $\mathrm{pH}$ value (4.0-6.0) than in soils characterized by higher $\mathrm{pH}$ values (5.0-7.0). In acid soils, nitrosamines are readily produced and various bacteria and fungi actively participate in this process. He added that high using of NPK fertilization rates over a 20 -year period significantly increased the number of bacteria, actinomycetes and fungi with 2, 2.5 and 2 fold, respectively, in comparison with control. These results are, to somewhat, 
similar in both seasons and are in harmony with those of many researchers (Abd El- Baky, 2005; Mahmoud et al., 2008 and Chuan-Chao et al., 2009).

Percentage of dead plants due to root-rot and or wilt was increased in solid plants compared with any of intercropping pattern. This result was observed in both seasons. In this respect, Abdel-Monaim and Abo-Elyousr (2012) studied the effect of intercropping lentil with anise, cumin, onion and garlic, and they mentioned that anise has the superior effect of decreasing damping-off and root-rot diseases and increased seed yield than other crops, while intercropping onion showed the lowest effect. Meanwhile, addition of nitrogen fertilization gradually increased Percentage of dead plants. These results are in line with those obtained by Barabasz et al. (2002) who found that increasing nitrogen fertilizer rates increased the counts of some fungi belonging to genera Aspergillus, Fusarium, Penecillium, Verticillium and others.

Also, Barabasz et al. (2002) found that mineral fertilization strongly affected the number of microorganisms and qualitative selection of whole communities of soil microorganisms. This may be due to the increase in height of sesame plants in case of (2:2) pattern rather than (3:1) pattern which intern resulted in dramatic changes in microclimate within and under plants, i.e. temperature and relative humidity. This microclimate plays as an incubator, which led to increase the density of soil microorganisms in case of $(2: 2)$ pattern. These results are in harmony with those obtained by Ismail (1994 and 2004) who found that disease incidence of cotton damping -off was increased under intercropping cotton with each of wheat and faba bean compared to cotton sole and/or intercropping with onion and garlic. However, it was noticed an increase in the percentage of dead plants in the individual case of peanut and sesame. The presence of other species of fungi and bacteria in soil of intercropping system may be playing a role in the inhibition of some pathogenic fungi (Eisa et al., 2006 and Ali et al., 2007). Competitive relationships which included the relative yield (RYs) and land equivalent ratio (LER) indicate that increasing sesame population to reach $50 \%$ of solid population did not exert heavy competition between both components. These results are coincided with those obtained by many researchers (El-Mihi et al., 1990; Gabr et al., 1993; Dahatonde et al., 1996; Badran, 2002 and Toaima et al., 2004).

More shading by sesame plants on peanut in the equal alternative pattern $(2: 2)$ might be the causal of peanut stem elongation. These results were similar in both tested seasons and in agreement with those obtained by many researchers (El-Mihi et al., 1990; Gabr et al., 1998 and Toaima et al., 2004).

A very interesting result is that both maximum and minimum pod yield values were obtained when the plant received the same rate of nitrogen indicating the paramount effect of intercropping pattern on yield of peanut. In this respect, Greish (1998) studied the effect of nitrogen fertilizer rates on peanut in monoculture and in association. He found that increasing $\mathrm{N}$ dose up to $45 \mathrm{~kg} \mathrm{~N} / \mathrm{fed}$. was associated with the highest average of all studied traits of peanut. These results are in accordance with those obtained by many researchers (Willey, 1979; Astatke et al., 1995; Mandimba, 1995; Pilbeam et al., 1995; Greish, 1998 and Ahmed et al., 2008). It is evident that the higher reduction in peanut intercropping systems as compared to 
sole peanut may be associated with the above ground competition for light between sesame and peanut in the mixture as reported by Willey (1979). The intra and inter competition for light may be attributed to the extremely higher growth vigour of sesame in (2:2) pattern, which over shaded the peanut and suppressed the yield quantity of peanut. Intercropping generally resulted in suppressing growth of the smaller companion plants because they intercept only a small fraction of photosynthetically active radiation as a result of competition of both components for light during initiation of growth and developing. It caused an inadequate supply of assimilates to the root because of shading and thus it limited root growth, and this might affect nodule formation and further $\mathrm{N}_{2}$ fixation. Nevertheless, it is evident that peanut heights increased gradually with increasing the nitrogen fertilizer rate up to the highest rate $(75 \mathrm{~kg} \mathrm{~N} / \mathrm{fed}$.) whatever the intercropping pattern. Similar trend was also observed for pod yield/fed. These results are in agreement with those obtained by many researchers (Willey, 1979; Abd El-Galil and Moursi, 2004 and Ahmed et al., 2008). Therefore, the researchers believe that infection of peanut by root-rot and/or wilt (dead plants) depended on the increase or decrease of $\mathrm{N}$ fertilizer rate than the intercropping system. Also, they recommended the application of intercropping system with a fertilization rate of $60 \mathrm{~kg} / \mathrm{fed}$. as a better productivity with less root-rot and/or wilt (dead plants) percentages. This could be considered when designing an effective integrated pest management program for the studied diseases and also for high and healthy peanut and sesame yield.

\section{$R$ e f e r e n c e s}

Abd El-Baky, A.A. 2005. Control of some onion rots in North Africa by field and storage treatments. Ph.D. Thesis, Inst. Afric. Res. \& Study, Cairo Univ., 109 pp.

Abd El-Galil, M.A. and Moursi, Faiza M. 2004. Some statistical models to detect the relation between yield and its components for intercropping experiments. J. Agric. Sci., Mansoura Univ., 29(10): 5483-5491.

Abdel-Monaim, M.F. and Abo-Elyousr, K.A.M. 2012. Effect of preceding and intercropping crops of lentil damping-off and root rot diseases in New ValleyEgypt. Crop Protec., 32: 41-46.

Abd El-Zaher, S.R.; Mohamed, Wafaa K. and Toaima, S.E.A. 2007. Intercropping maize with peanut under two plant distribution and three planting dates. Ann. of Agric. Sci., Moshtohor, 45(2): 545-560.

Ahmed, Zakia H.; Al-Mezori, A.M. and Duhoky, M.S. 2008. Effect of intercropping systems and nitrogen fertilizer on yield, yield component of corn (Zea mays L.) and peanut (Arachis hypogaea L.). J. Dohuk Univ., 11(1): 206-216.

Ali, M.A; Osman, Ettimad A.H.; Dawoud, Ensaf I.; Ibrahim, Thanaa F. and Amin, G.A. 2007. Optimization of the bioagent Bacillus subtilis biomass production and antibiosis against Acremonium strictum. J. Agric. Sci. Mansoura Univ., 32(5): 4075-4090.

Egypt. J. Phytopathol., Vol. 42, No. 1 (2014) 
Aly, A.A.; Abdel-Sattar, M.A. and Omar, M.R. 2006. Susceptibility of some Egyptian cotton cultivars to charcoal rot disease caused by Macrophomina phaseolina. J. Agric. Sci. Mansoura Univ., 31: 5025-5037.

Astatke, A.; Saleem, M.A.M.; and El-Waked, A. 1995. Soil water dynamics under cereal and forage legume mixtures on drained vertisols in the Ethiopian highlands. Agric. Water Management, 27: 17-24.

Badran, M.S. 2002. Solid versus intercropping sesame with groundnut at different sequences of sowing dates. III. Competitive relations. Alex. J. Agric. Res., 47(3): 31-39.

Barabasz, W.; Albinska, D.; Jaskowska, M. and Lipiec, J. 2002. Biological effects of mineral nitrogen fertilization on soil microorganisms. Polish. J. Environ. Studies, 11(3): 193-198.

Bergey, D.H. 1985. Bergey’s Manual of Systematic Bacteriology. Int. J. Syst. Bact., 408pp.

Booth, C. 1985. The Genus Fusarium. Kew, Surrey Commonwealth Mycological Institute, $2^{\text {nd }}$ Ed., $237 \mathrm{pp}$.

Botros, S.E. 1988. Studies on root stalk-rots of maize. M.Sc. Thesis, Fac. Agric. Assiut Univ.

Burgess, L.W. and Summerell, B. A. 1992. Mycogeography of Fusarium: Survey of Fusarium species in subtropical and semi-arid grassland soils from Queensland, Australia. Mycological Res., 96(9): 780-784.

Chuan-Chao, D.; Hui, X.; Wang, X.; Li, P.; Zhang, T.; Li, Y. and Tan, X. 2009. Intercropping peanut with traditional Chinese medicinal plants improves soil microcosm environment and peanut production in subtropical China. African J. Biotechnol., 8(16): 3739-3746.

Dahatonde, B.N.; Turkhede, A.B.; Kale, M.R. and Surgawanshi, B.M. 1996. Studies on intercropping groundnut and sesame. Pk. V. Res. J., 19(1): 83-84. (C.f. Field Crops Abster., 49(12): 9017).

Eisa, Nawal A.; El-Habbaa, G.M.; Omar, S.M. and El-Sayed, Sahar A. 2006. Efficacy of antagonists, natural plant extracts and fungicides in controlling wilt, root rot and chocolate spot pathogens of faba bean in vitro. Ann. Agric. Sci. Moshtohor, 44(4): 1547-1570.

El-Bramawy, M.A.S. 2003. Breeding Studies for Fusarium Wilt Resistance in Sesame (Sesamum indicum L.). Ph.D. Thesis, Suez Canal Univ., Egypt. 235pp.

El-Bramawy, M.A.S. 2006a. Inheritance of resistance to Fusarium wilt in some crosses under field conditions. Plant Protect. Sci., 42(2): 99-105.

El-Bramawy, M.A.S. 2006b. Inheritance of Fusarium wilt disease resistance caused by Fusarium oxysporum f.sp. sesame in some crosses under field conditions. Sesame and Safflower Newsletters, 21: 1-8. 
El-Deeb, A.A. and Ibrahim, E.M. 1998. Integrated control of peanut root and pod rot diseases and their effect on nodulation and $\mathrm{N}$-content of plants. Egypt J. Appl. Sci., 13(3): 442-458.

El Gindy, A.A. and Saad, R.R. 1990. Fungi in virgin and cultivated soil of Salhiah desert Egypt. Zentralblatt fur Mikrobiologie, 145: 547-551.

El-Mihi, M.A.; El-Gamal, A.S.; El-Masry, M.A. and Kamel, A.S. 1990. Growth and yield of sesame and groundnut in monoculture and association under different patterns and plant spacing. Proc. $4^{\text {th }}$ Conf. Agron., 11: 571-580.

El-Shehaby, A.I. and Morsy, S.M.A. 2005. Biological control of peanut damping-off disease by Bacillus sphaericus soil treatment. Egypt J. Agric. Res., 83(1): 1-9.

Ellis, M.B. 1971. Dematiaceous Hyphomycetes. Commonwealth Mycological Institute $(\mathrm{CAB})$, England.

Gabr, E.M.A.; Metwally, I.O.E. and El-Hawary N.A. 1993. Effect of different patterns of intercropping sesame with groundnut in sandy soils. J. Agric. Sci. Mansoura Univ., 18(12): 3419-3424.

Gangwar, R.K.; Choudhary, R.G. and Kumar, K. 2009. Effect of cultural practices and edaphic environment on chickpea wilt caused by Fusarium oxysporum f.sp. ciceri. J. Food Legumes, 22(4): 273-275.

Greish, M.H.M. 1998. Effect of preceding crops and nitrogen fertilizer on sunflower and peanut in monoculture and in association. Ann. Agric. Sci., Moshtohor, 36(3): 1349-1360.

Hasan, S.A.; El-Deeb, A.A. and Al-Korashy, M.A. 2002 Chemical and biological control of yellow pod rot of peanuts with reference to nodulation, oil, $\mathrm{N}$ content and yield. Egypt J. Appl. Sci., 17(5): 62-82.

Hilal, A.A.; Elian, M.I.; Metwally, A.H. and El-Deeb, A.A. 1990. Peanut diseases in Egypt, . Factors affecting healthy survival plants, pod rots and yield. Annu. Agric. Sci., Moshtohor, 28(3): 1557-1569.

Hussein, Samira M.A.; Shams, S.A.A. and El-Melegy, M.M. 2002. Effect of some intercropping patterns and foliar application with nutrients mixture on yield of maize and peanut. Ann. Agric. Sci. Moshtohor, 40(3): 1427-1447.

Ismail, A.E.A. 1994. Effect of intercropping soybean and maize plants on incidence of some soil fungal diseases. Ph.D. Thesis, Fac., Agric., Zagazig Univ., 220 pp.

Ismail, A.E.A. 2004. Cotton damping-off diseases control under intercropping system with some winter crops. J. Agric. Sci. Mansoura Univ., 29(7): 3897-3905.

Jacobi, J.C. and Backman, P.A. 1994. Comparison of yield, value and seed quality factors of florunner and southern runner peanut. Peanut Sci., 21(1): 28-34.

Johansen, L.E.; Curi, E.A.; Bonf, J.H. and Fribourg, H.A. 1960. Methods for studying soil microflora plant disease relationship. $2^{\text {nd }}$ Ed. Burges Publishing Co., 77 pp. 
Khalifa, M.A. 2003. Pathological studies on charcoal-rot disease of sesame. Ph.D. Thesis, Fac. Agric., Moshtohor, Zagazig Univ., Benha Branch. 295 pp.

Mahmoud, Nagwa M.A.; Morsy, K.M. and Mazen, M.M. 2008. Effect of intercropping soybean and maize on soybean damping-off disease and relevant effect on the rhizosphere microorganisms and antagonistic microbes. J. Agric. Sci. Mansoura Univ., 33(3): 1959-1970.

Mandimba, C.R. 1995. Contribution of nodulated legumes on the growth of Zea mays L. under various cropping systems. Symbiosis, 19: 213-222.

Mehan, V.K.; Mayee, C.D. and Donald, M.C. 1995. Stem and pod rot of ground nut. ICRISAT Information Bul., 44: 23.

Pilbeam, C.J.; Wood, M. and Mugane, P.G. 1995. Nitrogen use in maize-grain legume cropping systems ii semi-arid Kenya. Biol. Fertiliz. Soils, 20: 57-62.

Ryszkowski, L.; Szajdak, L. and Karg, J. 1998. Effect of continuous cropping of rye on soil biota and biochemistry. Ctit. Rev. Plant Sci., 17: 225-244.

Sangalang, A.E.; Burgess, L.W.; Backhouse, D.; Duff, J. and Wurst, H. 1995. Mycogeography of Fusarium species in soils from tropical, arid and Mediterranean regions of Australia. Mycological Res., 99(5): 523-528.

Snedecor, G.W. and Cochran, W.G. 1998. Statistical Methods. $7^{\text {th }}$ Ed. Iowa State Univ., Press, Ames, Iowa, U.S.A.

Toaima, S.E.A.; Atalla, R.A. and El-Sawy, W.A. 2004. Response of some peanut genotypes to intercropping with sesame in relation to yield and yield components. Ann. Agric. Sci., Moshtohor, 42(3): 903-916.

Willey, R.W. 1979. Intercropping-its importance and research needs. Part I: Competition and yield advantages. Field Crops Abstract, 32: 1-10.

Willey, R.W.; Matarajan, N. and Bhatnagar, V.S. 1983. Better food crops for intercropping with annual crops. Ciba Foundation Symposium, 97. Pitman Books, London, pp. 93-100.

(Received 27/02/2014;

in revised form 30/03/2014) 


\section{التحميل والتسميا النيتروجينى فى مكافحة

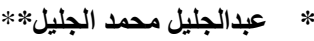

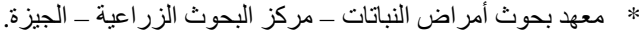 \\ ** معهد بحوث المحاصيل الحقلية ـ مركز البحوث الزر البحثة ـ الجيزة.}

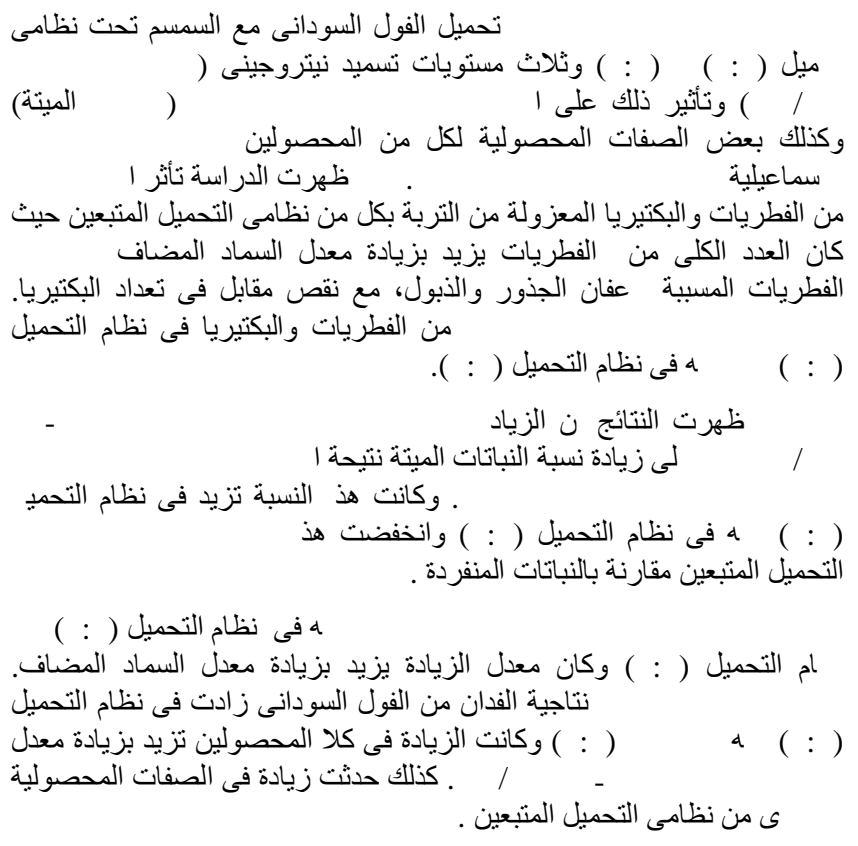

